\title{
Contribution to the study of frontal sinus familial similarity based on genealogically documented individuals (Bohemia, $19^{\text {th }}$ to $20^{\text {th }}$ centuries)
}

\author{
Jan Cvrček $^{1,2}$ \& Petr Velemínský ${ }^{1}$ \\ ${ }^{1}$ Department of Anthropology, National Museum in Prague, Cirkusová 1740, Prague 20, 19300 Horní \\ Počernice, Czech Republic; jan.cvrcek@nm.cz, petr.veleminsky@nm.cz \\ ${ }^{2}$ Department of Anthropology and Human Genetics, Faculty of Science, Charles University, Viničná \\ 1594/7, 12800 Prague 2, Czech Republic
}

Cvrček J. \& Velemínský P., 2020: Contribution to the study of frontal sinus familial similarity based on genealogically documented individuals (Bohemia, 19th to 20th centuries). - Journal of the National Museum (Prague), Natural History Series 189: 21-30.

\begin{abstract}
The issue of the influence of biological relatedness on frontal sinus patterns is still the subject of discussion. Research possibilities worldwide are however limited by the lack of genealogically documented skeletal remains. This study presents the results of analyses of seven identified 19th-20th century skulls from two families, discovered in the collections of the Hrdlička Museum of Man. Anteroposterior X-rays were created and the morphology of the frontal sinuses was evaluated using two approaches: A) a simple visual assessment indicating shared or similar features; and B) calculation of the degree of similarity based on a scoring system. With both approaches, the results of family relationship assessments were best reflected in the first family, between individuals with the smallest degree of biological distance. In the second family, which had more distant relationships compared to the first, the positive relationship between biological distance and degree of similarity was not clearly apparent. Although this is a small sample with a small number of generations, our findings support the conclusions of previous studies, i.e. that the degree of similarity between individuals decreases with their increasing biological distance.
\end{abstract}

Keywords: frontal sinus, morphology, X-ray, inbreeding, $19^{\text {th }}-20^{\text {th }}$ century

Received: September 8, 2020 | Accepted: October 1, 2020| Published on-line: October 15, 2020

\section{Introduction}

Osteological samples with known family relationships, which allow study of the possible influence of genetic factors on morphological and metric features of the human skeleton, are very rare worldwide (Gavrus-Ion et al. 2017). They are, however, of irreplaceable significance, because the conclusions of studies based on such material can be applied to anonymous, (pre)historic burial grounds with individuals whose relationships are unknown or are indicated by archaeological findings (Adachi et al. 2006, Meyer et al. 2012, Brown 2015, Velemínský et Cvrček 2020). One of the features that helps reveal possible biological rela- 
tionships between individuals is the frontal sinus, its morphology and dimensions being displayed using both radiographs and CT scans (e.g. Szilvássy 1986, Cvrček et al. 2020).

Morphological similarities of the frontal sinus between closely related individuals were observed in the first half of the 20th century (Leicher 1928, Schwarz 1928, Turpin et al. 1942). Although the formation of the frontal sinus is unique in each individual, like fingerprints, and there is no absolute agreement even between monozygotic twins (Asherson 1963, Christensen et Hatch 2018), it is possible to identify the biological affinity of individuals; at the same time, however, frontal sinuses cannot be used to identify their exact relationship (Cameriere et al. 2008). The evaluation of morphological features can, though, be considered subjective (Asherson 1963). Therefore, the degree of similarity of individuals is also determined from the dimensions of the frontal sinuses (e.g. Slavec 2005), and in particular a significant relationship between their maximum height and the biological distance of individuals has been demonstrated (Kjaer et al. 2012, Cvrček et al. 2020). Sex differences in frontal sinus size between biologically related individuals have not been found (Cvrček et al. 2020).

Nevertheless, it has been shown that the evaluation of dimensions can be negatively affected by even a slight change in the setting of the skull during the taking of an X-ray image (Nikolova et al. 2018), and that therefore a morphological evaluation might ultimately be "more objective", especially if a scoring system is used (Besana et Rogers 2010). This approach has already proven useful for this purpose (Cameriere et al. 2008), a significant relationship between the degree of morphological similarity and the degree of biological distance between individuals having been found (Cvrček et al. 2020), i.e. the smaller the biological distance, the greater the degree of similarity. It turned out, however, that a simple visual assessment of the morphology of the frontal sinus (Szilvássy 1986) was irreplaceable, because statistical methods do not allow the capture of specific shared features, especially if the osteological material is incompletely preserved, or the number of individuals is very small or even just a pair, where a comparison of the values of the degree of morphological similarity cannot be used (Cvrček et al. 2020).

The authors were given the opportunity to examine two small samples of genealogically documented skulls from the collections of the Hrdlička Museum of Man in the Faculty of Sciences of Charles University in Prague. The aim of this contribution is 1) to answer the question as to what extent the morphological similarity of the frontal sinuses corresponds to documented family relationships; and 2) assess whether there are shared individual features between individuals that support these relationships.

\section{Material and methods}

\section{Material}

The material consists of seven skulls from two generations of biologically unrelated families (families A and B) dating to the $19^{\text {th }}$ and $20^{\text {th }}$ centuries (Fig. 1); all the familial relationships and other biographical data were known. For ethical reasons, only their initials and years of birth and death are given here:

\section{Family A}

No. 1: Male J. R. (1835-1892), Prague goldsmith. Died of exhaustion.

No. 2: Female E. R. (1831-1887), biologically unrelated wife of J. R. Died of kidney inflammation.

No. 3: Male E. R. (1867-1889), son of J. R. and E. R. Died of pulmonary tuberculosis and spewing blood.

\section{Family B}

No. 1: Male J. R. (1816-1894), one of most important businessmen in the AustroHungarian Empire. He died of marasmus senilis. 
No. 2: Female M. A. R. (1819-1855), the first cousin and also first wife of J. R. (their fathers being brothers). She died of paralysis of the lungs due to typhus.

No. 3: Female J. C.R. (1836-1920), the second and biologically unrelated wife of J. R. She died of pneumonia.

No. 4: Female C. R. (1857-1930), wife of one of the inbred sons of first cousins J. R. and M. A. R., and at the same his first cousin again (her mother was both sister of his mother and first cousin of his father). She had three sons and one daughter with her husband, but according to available archive documents all remained childless, and this branch of the family became extinct. She died of tuberculosis and atherosclerosis.

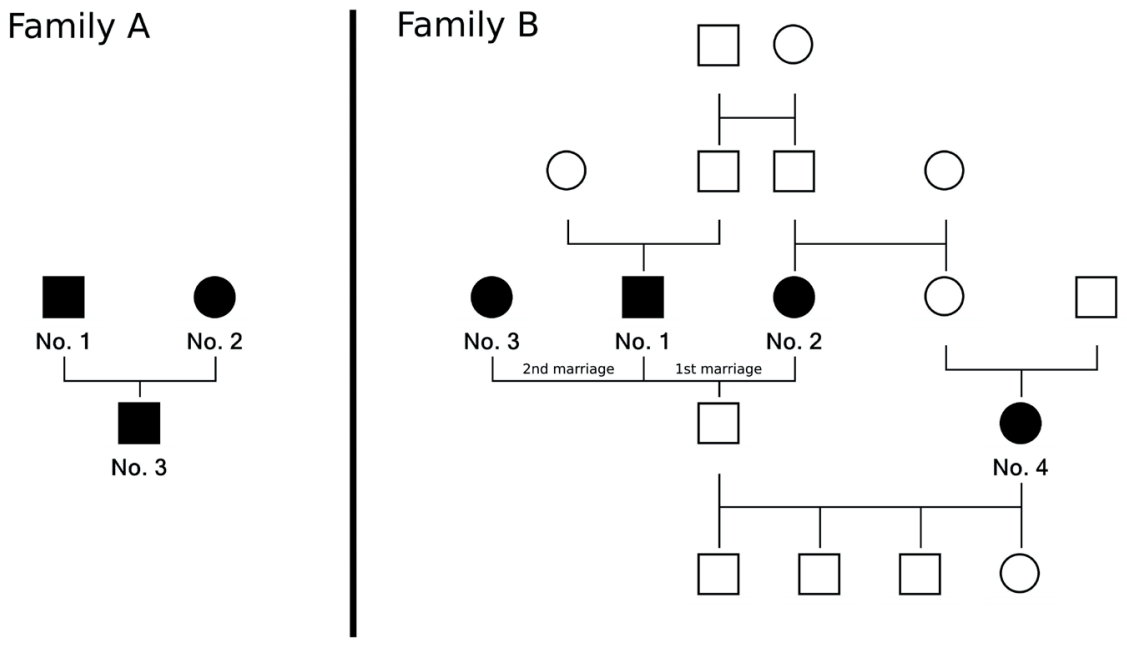

Fig. 1. Graphical expression of family relationships of evaluated individuals from families A and $B$.

Biographical data were verified by genealogical research in the Prague City Archives, and the State District Archives in Most (a branch of the State Regional Archives in Litoměřice, Czech Republic). The skulls are part of the collections of the Hrdlicka Museum of Man. The tombs of both families were looted in the second half of the $20^{\text {th }}$ century, and the material was probably obtained for the museum by its director, the anthropologist prof. Vojtěch Fetter (1905-1971). Although the skulls were saved and their identification preserved, archival sources indicate that the postcranial parts of the associated skeletons, and even the whole bodies of other family members, were cremated or lost, e.g. the remains of the sons of individuals Nos. 1 and 2 from family B. Only the mummified forearm and hand of female No. 4 from family B were preserved. Incidentally, the skulls of all the members of family B were also more or less covered with remnants of mummified soft tissues and hair, so analysis of cranial non-metric traits (e.g. Cvrček et al. 2018) could not be included in this study, while analysis of dental non-metric traits was made impossible by the intra-vital loss of most teeth in all individuals from both families.

\section{Methods}

An anteroposterior radiograph of the skull oriented in the Frankfurt Plain was taken for each individual. Radiographs were performed using computed radiography (CR) at the Department of Anthropology, National Museum, Prague. A Bucky grid was used, the standard distance between the focal point and the CR cassette was $1.2 \mathrm{~m}$, with tube voltages ranging between $80-85 \mathrm{kw}$ and beam intensity between $3.5-5 \mathrm{mAs}$. The skulls were stabilized with 


\begin{tabular}{|c|c|c|}
\hline Category & Classification & Class number \\
\hline Total size & $\begin{array}{l}\text { Small }(0-6) \\
\text { Middle }(6-12) \\
\text { Large }(12-18) \\
\text { Very large }(>18)\end{array}$ & $\begin{array}{l}1 \\
2 \\
3 \\
4\end{array}$ \\
\hline Bilateral asymmetry & $\begin{array}{l}\text { Symmetry }(100-80) \\
\text { Slight asymmetry }(80-60) \\
\text { Moderate asymmetry }(60-40) \\
\text { Strong asymmetry }(40-20) \\
\text { Extreme asymmetry }(<20)\end{array}$ & $\begin{array}{l}1 \\
2 \\
3 \\
4 \\
5\end{array}$ \\
\hline Superiority & $\begin{array}{l}\text { Absent } \\
\text { Left equal to right } \\
\text { Left greater than right } \\
\text { Right greater than left }\end{array}$ & $\begin{array}{l}0 \\
1 \\
2 \\
3\end{array}$ \\
\hline $\begin{array}{l}\text { Outline of upper border for left side } \\
\text { and right side separately }\end{array}$ & $\begin{array}{l}\text { Absent } \\
\text { Smooth } \\
\text { Scalloped with } 2 \text { arcades } \\
\text { Scalloped with } 3 \text { arcades } \\
\text { Scalloped with } 4 \text { arcades } \\
\text { Scalloped with above } 5 \text { arcades }\end{array}$ & $\begin{array}{l}0 \\
1 \\
2 \\
3 \\
4 \\
5\end{array}$ \\
\hline Partial septa & $\begin{array}{l}\text { Absent } \\
\text { Present in the left side } \\
\text { Present in the right side } \\
\text { Present in the both sides }\end{array}$ & $\begin{array}{l}0 \\
1 \\
2 \\
3\end{array}$ \\
\hline Supraorbital cells & $\begin{array}{l}\text { Absent } \\
\text { Present in the left side } \\
\text { Present in the right side } \\
\text { Present in the both sides }\end{array}$ & $\begin{array}{l}0 \\
1 \\
2 \\
3\end{array}$ \\
\hline $\begin{array}{l}\text { Shape for left side and right side } \\
\text { separately }\end{array}$ & $\begin{array}{l}\text { Bean shape } \\
\text { Leaf shape } \\
\text { Fan shape } \\
\text { Pyramid shape }\end{array}$ & $\begin{array}{l}1 \\
2 \\
3 \\
4\end{array}$ \\
\hline $\begin{array}{l}\text { Lateral range for left side and right } \\
\text { side separately (own category) }\end{array}$ & $\begin{array}{l}\text { Absent } \\
<1 / 3 \text { border of orbit } \\
<1 / 2 \text { border of orbit } \\
>1 / 2 \text { border of orbit } \\
>\text { lateral border of orbit }\end{array}$ & $\begin{array}{l}0 \\
1 \\
2 \\
3 \\
4\end{array}$ \\
\hline
\end{tabular}

Tab. 1. Visual features and their classifications for expression of frontal sinus morphology by Szilvássy (1986), Yoshino et al. (1987), and Reichs (1993).

a standard pad; the distance from the face of the skull to the detector surface was about $3 \mathrm{~cm}$, so partially geometric magnification was taken into account by the enclosed scale.

The skulls were completely preserved, without autopsy cuts or significant post-mortem destruction, so all of the displayed frontal sinuses could be cut along a plane that passes through the upper orbital margins and is parallel to the Frankfurt plane. This limit defined the supraorbital line (SOL; Nikolova et al. 2018). A portion superior to this plane was further examined (Fig. 2). 2D images (silhouettes) of the obtained sinuses of individuals were created in Inkscape 0.91.

Using a simple visual assessment (Szilvássy et al. 1987), morphologically identical or analogous structures were observed, which were then graphically highlighted. The frontal sinus morphological patterns of all the individuals were expressed using eight categories 


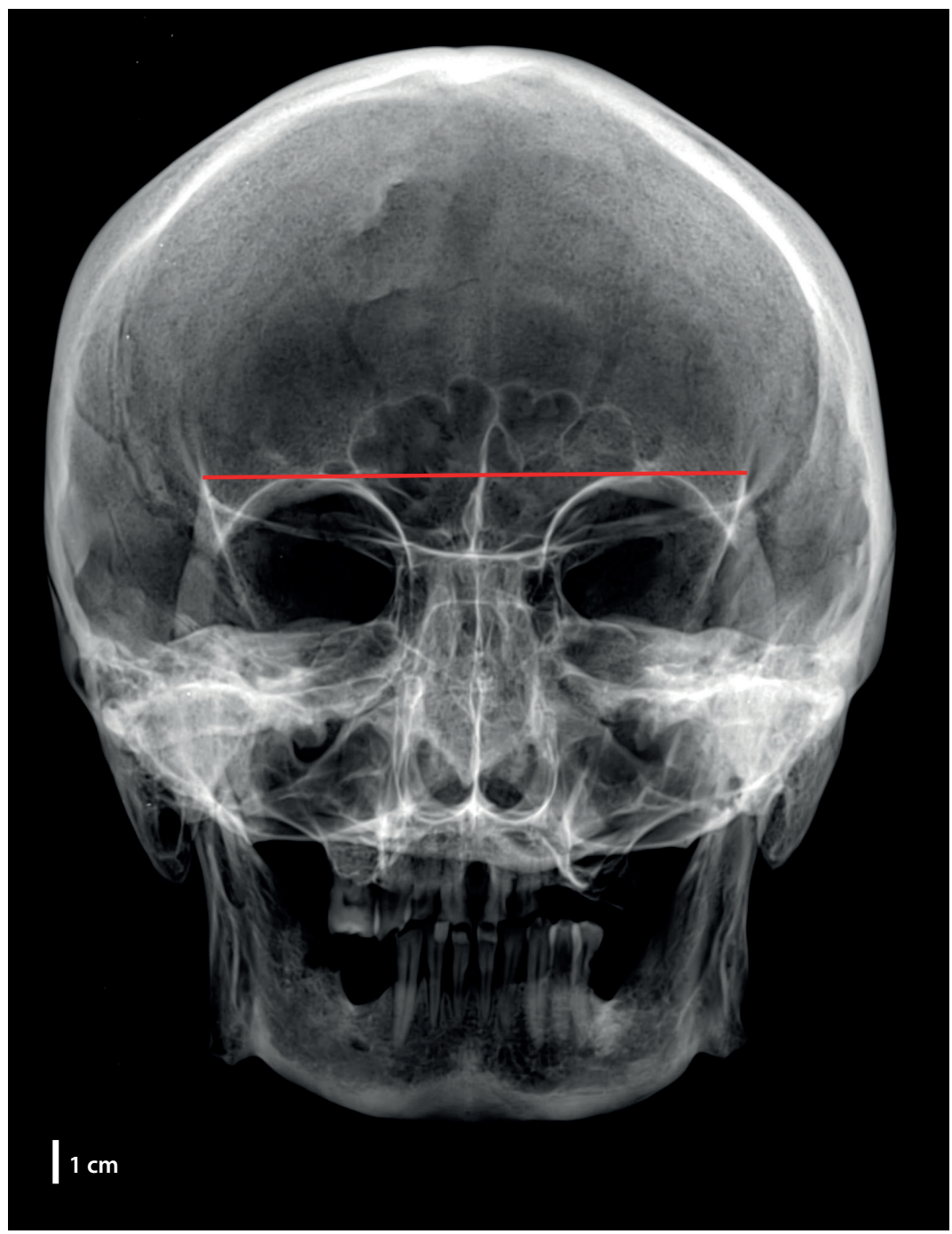

Fig. 2. Anteroposterior radiograph of the skull with "supraorbital line" (SOL, red line), family $A$, individual No. 1.

after Szilvássy (1986), Yoshino et al. (1987), and Reichs (1993) (Tab. 1). Most of these have been shown to be independent (Cameriere et al. 2005), and the previous use of this set of variables (Cvrček et al. 2020) demonstrated their applicability for this purpose. The degree of the morphological similarity ("MS") of individuals based on class numbers of the categories above (patterns) was calculated using cosine similarity (Singhal 2000, Cvrček et al. 2020). This method measures the cosine of the angle between two $n$-dimensional vectors of an inner product space. The vectors are individuals within a family. In space, vectors are determined using the values of individual morphological features (Tab. 1). The similarity between individuals is calculated using cosine and can be converted to a distance. 


\section{Results}

\section{Family A}

Based on simple visual assessment, a greater similarity is visible between father No. 1 and son No.3, with a greater number of shared features between them than between mother No. 2 and son No. 3 (Fig. 3). The most characteristic feature that is shared by father and son, and which clearly supports their documented relationship, is a small separated lobe above the right orbit (Fig. 3, blue arrow).

The degree of the morphological similarity calculated using cosine similarity confirmed the finding based on the simple visual assessment. The greatest value is between father No. 1 and son No. 3, similarity is also apparent between mother No. 2 and son No. 3, and the least similarity is between unrelated spouses Nos. 1 and 2 (Tab. 2).

\section{Family B}

A simple visual assessment shows no visible similarity between biologically related individuals in this family, such as first cousins and spouses Nos. 1 and 2, or these individuals and their niece/daughter-in-law No. 4 (Fig. 4). Female No. 4, unlike the

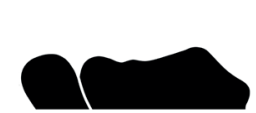

No. 1

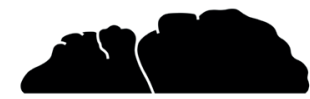

No. 2

No. 4

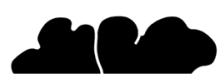

No. 3

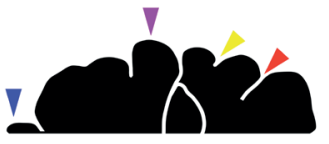

No. 1

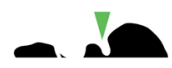

No. 2

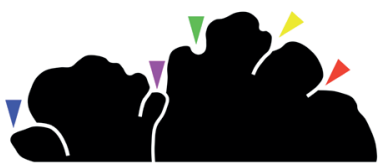

No. 3

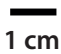

Fig. 3. Anteroposterior views of frontal sinuses above their SOL, from X-rays of closely related individuals Nos. 1-3 from family A. Examples of various shared morphological similarities (arrows) are marked with the same colors.

\begin{tabular}{|c|c|c|c|}
\hline & $\mathbf{1}$ & $\mathbf{2}$ & $\mathbf{3}$ \\
\hline $\mathbf{1}$ & - & 0.82 & 0.84 \\
\hline $\mathbf{2}$ & & - & 0.97 \\
\hline $\mathbf{3}$ & & & - \\
\hline
\end{tabular}

Tab. 2. The degree of similarity of individuals Nos. 1-3 from family A by frontal sinus morphology, calculated based on cosine similarity. The higher value, the darker color.

\begin{tabular}{|c|c|c|c|c|}
\hline & $\mathbf{1}$ & $\mathbf{2}$ & $\mathbf{3}$ & $\mathbf{4}$ \\
\hline $\mathbf{1}$ & - & 0.82 & 0.84 & 0.76 \\
\hline $\mathbf{2}$ & & - & 0.97 & 0.55 \\
\hline $\mathbf{3}$ & & & - & 0.52 \\
\hline $\mathbf{4}$ & & & & - \\
\hline
\end{tabular}

Tab. 3. The degree of similarity of individuals Nos. 1-4 from family B by frontal sinus morphology, calculated based on cosine similarity. The higher value, the darker color.

other individuals, shows hypoplasia of the right frontal sinus, and her left sinus is greatly reduced.

In this case too, the calculated similarity corresponds to the simple visual assessment. There is no positive relationship between the degree of similarity and the degree of biological distance between individuals. Although there is a relatively higher value between first cousins Nos. 1 and 2 , the highest value occurs between biologically unrelated individuals Nos. 2 and 3, and Nos. 1 and 3. (Tab. 3). 


\section{Discussion}

The results of visual assessment showed several identical or similar features between biologically related individuals in family A, unlike the biologically related individuals in family B, among whom no clear similarities were found. This is most likely due to the fact that there are smaller biological distances in family A, i.e. a greater degree of relatedness, than between the members of family B. This relates to a father and son or mother and son (coefficient of relationship $r=0.5)$ on the one hand, and an aunt/niece $(r=0.25)$, first cousins $(r=0.125)$, and cousin of mother/daughter of cousin $(r=0.0625)$ on the other. This finding was confirmed by the calculated degree of similarity between individuals, in family $A$ the values correspond more to documented family relationships than in family B. In family B, there is even greater similarity between biologically unrelated individuals Nos. 1 and 3, or Nos. 2 and 3, than between individuals with biological relationships, such as individuals Nos. 1 and 4, or 2 and 4. This may be the result of chance, such cases have already been described (Cvrček et al., 2020). Although significant similarities were found in some cases even between first cousins in previous studies, both on the basis of the evaluation of features and according to calculations of similarity, nevertheless the most obvious similarities were primarily between closer relatives, such as parents and children, siblings, and grandparents and grandchildren (Cvrček et al. 2020). This also applies, for example, to osteological non-metric traits (Velemínský et Dobisíková 2005, Cvrček et al. 2018). The results of this study therefore confirm these earlier conclusions. A graphical expression of the relationship between similarity and relatedness (Cvrček et al. 2018, 2020) is impossible in these families, due to the small number of individuals and the small number of generations.

From a methodological point of view, this study confirms that a simple visual assessment of similarity may not be so burdened with subjectivity as assumed (Asherson 1963), even with respect to a scoring system (Besana et Rogers 2010), because similar results were arrived at on the basis of both approaches (Cvrček et al. 2020). Furthermore, a simple visual assessment (Szilvássy 1986), unlike scoring systems (e.g. Cameriere et al. 2005, 2008; Besana et Rogers 2010), allows the assessment of incompletely preserved skeletal remains, for which the missing parts cannot be exactly reconstructed (Kuželka 2018, Drtikolová Kaupová et al. 2020). At the same time, the situation may arise where the same frontal sinus pattern exists in two individuals based on the scoring system, but they differ visually (Cvrček et al. 2020). Although efforts have recently been made towards exact research of the frontal sinuses using computer tomography (CT) and/or focussing on their dimensions (Chaiyasate et al. 2007, Kjaer et al. 2012), X-ray examination with a focus on morphology appears to be sufficient, even with regard to preservation limits. The main advantage of morphological evaluation over dimensional assessments remains the variability of frontal sinus patterns. This is so great that although it is possible to detect the biological affinity between individuals (Cameriere et al. 2008), sinus formation is unique to each individual, similar to a fingerprint (Christensen et Hatch 2018).

Even though there are two proven consanguineous marriages in family B, their possible consequences on the morphology of the frontal sinuses cannot be studied in this case. For this knowledge, it would be necessary to have the skulls of the children of the parents and at the same time the first cousins Nos. 1 and 2, or the children of their son and related daughterin-law No. 4; unfortunately these have not been preserved. It has however previously been found that inbreeding can affect some parameters of the frontal sinus, reducing their variability, albeit not always statistically significantly (Cvrček et al. 2020).

Although the studied samples include a small number of individuals from only two generations, this study significantly contributes to knowledge of the possible influence of family relationships on frontal sinus pattern inheritance, because this topic is still under discussion (Latiff et al. 2009, Ito et al. 2015). 


\section{Acknowledgements}

The authors greatly thank Z. Schierová and M. Galetová (Hrdlicka Museum of Man, Faculty of Science, Charles University, Prague) for the opportunity to study documented osteological collections, M. Jantač (Department of Anthropology, National Museum, Prague) for making radiographs of the skulls, T. Jor (Department of Zoology, Faculty of Science, Charles University, Prague) for help with calculations of degrees of similarity, F. Fortin (Czech Genealogy and Heraldry Society in Prague) for his help with the genealogical research, and A. Millar for revising the text.

We would also like to thank both reviewers, Alena Šefčáková (Slovak National Museum) and Zdeněk Tvrdý (Moravian Museum), for the comments that led to the improvement of this contribution.

\section{Grant sponsorship}

Charles University Grant Agency (Grant Number: GAUK 1276217); Ministry of Culture of the Czech Republic (DKRVO 2019-2023/7.I.b, 00023272).

\section{References}

Adachi N., Suzuki T., Sakaue K., Takigawa W., Ohshima N., Dodo, Y., 2006: Kinship analysis of the Jomon skeletons unearthed from a double burial at the Usu-Moshiri site, Hokkaido, Japan. -Anthropological Science 114: 29-34. https://doi.org/10.1537/ase.041228

Asherson N., 1963: The correlation of the forms of the frontal sinuses of twins. - Reports Institute of Laryngology and Otology 14: 1-26.

Besana J.L., Rogers T.L., 2010: Personal identification using the frontal sinus. - Journal of Forensic Sciences 55: 584-589. https://doi.org/10.1111/j.1556-4029.2009.01281.x

Brown K.A., 2015: Placing Children in Society. Using DNA to Identify Sex and Kinship of Child Skeletal Remains, and Implications for Gender and Social Organization. - In G. Coscunsu (ed.): The Archaeology of Childhood, Interdisciplinary Perspectives on an Archaeological Enigma, pp. 129-147. Albany: State University of New York Press.

Cameriere R., Ferrante L., Mirtella D., Rollo F.U., Cingolani M., 2005: Frontal sinuses for identification: quality of classifications, possible error and potential corrections. - Journal of forensic sciences 50, 4: 770-773. https://doi.org/10.1520/jfs2004343

Cameriere R., Ferrante L., Molleson T., Brown B., 2008: Frontal Sinus Accuracy in Identification as Measured by False Positives in Kin Groups. - Journal of Forensic Sciences 53: 1280 1282. https://doi.org/10.1111/j.1556-4029.2008.00851.x

Chaiyasate S., Baron I., Clement P., 2007: Analysis of paranasal sinus development and anatomical variations: a genetic study in twins. - Clinical Otolaryngology 32: 93-97. https://doi.org/10.1111/j.1365-2273.2007.01404.x

Christensen A.M., Hatch G.M., 2018: Advances in the use of frontal sinuses for human identification. - In K.E. Latham, E.J. Bartelink, M. Finnegan (eds.): New perspectives in forensic human skeletal identification, pp. 227-240. London: Elsevier, Academic Press. https://doi.org/10.1016/b978-0-12-805429-1.00020-x

Cvrček J., Velemínský P., Dupej J., Vostrý L., Brůžek J., 2018: Kinship and morphological similarity in the skeletal remains of individuals with known genealogical data (Bohemia, 19th to 20th centuries): A new methodological approach. - American Journal of Physical Anthropology 167: 541-556. https://doi.org/10.1002/ajpa.23683

Cvrček J., Rmoutilová R., Čechová M., Jor T., Velemínská J., Brůžek J., Naňka O., Velemínský P., 2020: Biological relationships and frontal sinus similarity in skeletal remains with known genealogical data. -Journal of Anatomy 237:798-809. https://doi.org/10.1111/joa.13246

Drtikolová Kaupová S., Velemínský P., Cvrček J., Džupa V., Kuželka V., Laboš M., Němečková A., Tomková K., Zazvonilová E., Kacki S., 2020: Multiple occurrence of premature polyarticular osteoarthritis in an early medieval Bohemian cemetery (Prague, Czech Republic). 
- International Journal of Paleopathology 30: 35-46. https://doi.org/10.1016/j. ijpp.2020.04.004

Gavrus-Ion A., Sjøvold T., Hernández M., González-José R., Torné M.E.E., Martínez-Abadíaz N., Esparza M., 2017: Measuring fitness heritability: Life history traits versus morphological traits in humans. - American Journal of Physical Anthropology 164: 321-330. https:// doi.org/10.1002/ajpa.23271

Ito T., Kawamoto Y., Hamada Y., Nishimura, T. D., 2015: Maxillary sinus variation in hybrid macaques: implications for the genetic basis of craniofacial pneumatization. - Biological Journal of the Linnean Society 115: 333-347. https://doi.org/10.1111/bij.12528

Kjaer I., Pallisgaard C., Brock-Jacobsen M.T., 2012: Frontal sinus dimensions can differ significantly between individuals within a monozygotic pair, indicating environmental influence on sinus size. - Acta Oto-Laryngologica 132: 988-994. https://doi.org/10.310 9/00016489.2012.677064

Kuželka, V. 2018: Antropologický výzkum kosterních pozůstatků nalezených při archeologickém výzkumu v areálu zámeckého parku v Jilemnici u gotického kostela sv. Alžběty [Anthropological research of skeletal remains found during archaeological research in the area of the castle park in Jilemnice near the Gothic church of St. Elizabeth]. - Z Českého ráje a podkrkonoší 31: 206-225. [In Czech.]

Latiff A.A., Das S., Othman F.B., 2009: Commentary on: Cameriere R, Ferrante L, Molleson T, Brown B. Frontal sinus accuracy in identification as measured by false positives in kin groups. - Journal of Forensic Sciences 53: 1280-1282. https://doi. org/10.1111/j.1556-4029.2009.00996.x

Leicher H., 1928: Vererbung anatomischer Variationen der Nase, ihrer Nebenhöhlen und des Gehörgangs. - In 0. Korner (ed.): Die Ohrenheilkunde der Gegenwart und ihre Grenzgebiete in Einzeldarstellungen. München: J. F. Bergmann.

Meyer C., Ganslmeier R., Dresely V., AltK.W., 2012: New Approaches to the Reconstruction of Kinship and Social Structure Based on Bioarchaeological Analysis of Neolithic Multiple and Collective Graves. - In J. Kolář \& F. Trampota (eds.): Theoretical and Methodological Considerations in Central European Neolithic Archaeology, pp. 11-23. Oxford: BAR International Series 2325.

Nikolova S., Toneva D., Georgiev I., Lazarov N., 2018: Digital radiomorphometric analysis of the frontal sinus and assessment of the relation between persistent metopic suture and frontal sinus development. - American Journal of Physical Anthropology 165: 492-506. https://doi.org/10.1002/ajpa.23375

Reichs K.J., 1993: Quantified comparison of frontal sinus patterns by means of computed tomography. - Forensic Science International 61: 141-168. https://doi. org/10.1016/0379-0738(93)90222-v

Schwarz M., 1928: Die Form verhhältnisse der Nasenscheidewand bei 84 Zwillingspaaren (53 Eineeigen und 31 Zweieigen). - Archiv für klinische und experimentelle OhrenNasen- und Kehlkopfheilkunde 119: 291-300.

Slavec Z.Z., 2005: Identification of family relationships by epigenetic traits. -Anthropologischer Anzeiger 63: 401-408. https://doi.org/10.1127/anthranz/63/2005/401

Singhal A., 2000: Modern Information Retrieval: A Brief Overview. - IEEE Data Engineering Bulletin 24: 35-43.

Szilvássy J., 1986: Eine neue Methode zur inraserialen Analyse von Gräberfeldern. - B. Herrmann (ed.): Innovative Trends in der Prähistorischen Anthropologie, Vol. 7, pp. 5161. Berlin: Berliner Gessellschaft für Anthropologie, Ethnologie und Urgeschichte.

Szilvássy J., Kritscher H., Teschler-Nicola M., 1987: Zur Verwandtschaftsanalyse von Skeletten aus ur- und frühgeschichtlichen Gräberfeldern. - Annalen des Naturhistorischen Museums in Wien 88/A: 183-205.

Turpin R., Tisserand M., Bernyer G., Caspar-Fonmarty M., 1942: Etude corrélative des sinus frontaux des jumeaux. - Comptes Rendus des Seances de la Societe de Biologie et des ses Filiales 136: 203-205. 
Velemínský, P., Cvrček J., 2020: Antropologická a paleopatologická charakteristika jedinců z Mikulovic: Morfologická variabilita nemetrických znaků a morfologická podobnost jedinců [Anthropological and palaeopathological description of individuals from Mikulovice: Morphological variability of non-metric traits and morphological similarity of individuals]. - In: M. Erneé (ed.): Mikulovice: Pohřebiště starší doby bronzové na Jantarové stezce. Památky archeologické, Supplementum 21, pp. 379-396. Prague: Institute of Archaeology of the Czech Academy of Sciences. [In Czech.]

Velemínský P., Dobisíková M., 2005: Morphological likeness of the skeletal remains in a Central European family from 17th to 19th century. - Homo 56: 173-196. https://doi. org/10.1016/j.jchb.2005.05.005

Yoshino M., Miyasaka S., Sato H., Seta S., 1987: Classification system of frontal sinus patterns by radiography. Its application to identification of unknown remains. - Forensic Science International 34: 289-299. https://doi.org/10.1016/0379-0738(87)90041-7 